\title{
Whales entangled in deep sea cables
}

\author{
BRUCE C. HeEzEN
}

(Received 7 January 1957)

\begin{abstract}
Fourteen instances of whales entangled in submarine cables are reported. Ten entanglements occurred off the Pacific coast of Central and South America. Six cases occurred in about 500 fathoms, with 620 fathoms the maximum depth reported. Five entanglements occurred in the period, February-March-April. All whales positively identified were sperm whales. The submarine cable was generally wrapped around the jaw and often around the flukes and fins. The cable was rarely broken but always badly mauled. The entanglements often occurred near former repairs where there is a chance for extra slack cable on the bottom. Two photographs of a sperm whale entangled in a cable and one photograph of a whale-jaw entangled in a cable are presented.

It is concluded that sperm whales often swim along the sea floor in depths as great as 620 fathoms. It is suggested that the whales become entangled while swimming along with their jaw plowing through the sediment in search of food. It is possible that the whales attack tangled masses of slack cable mistaking them for items of food.
\end{abstract}

\section{INTRODUCTION}

THERE is considerable interest in the depths to which whales dive in the ocean. Physiologists are interested in the pressures that whales can withstand. Workers in underwater sound are interested in the depths where they can expect whale noises; the same workers when using fish-finding gear and interpreting fish and plankton scattering layers are interested in what depths they can expect echoes from whales. The depth to which whales dive to feed has significance concerning the food cycle in whale grounds.

It has been reported that a sperm whale dives to depths of 500 fathoms (LAURIE, 1933) as a sperm whale became entangled in a submarine cable being repaired in that depth. This conclusion was apparently based on a single report. The possibilities that the whale became entangled at an intermediate depth during repairs, or that the dead whale was carried there by a current from shallow water casts some doubt on this conclusion. The present paper present more information on the entanglement of whales in submarine cables at relatively great depths.

\section{REPORTS OF DAMAGE TO SUBMARINE CABLES INFLICTED BY WHALES}

Fourteen reports of cable damage by whales have been found on searching all available cable failure records of the Western Union Telegraph Company, the Commercial Cable Company, the All America Cable Company, and the Commercial Pacific Company (Table 1). Ten were off the Pacific coast of Central and South America (Fig. 1), one was in the Newfoundland area of the North Atlantic, two on the Atlantic coast of South America, and another off the west coast of India. The fourteen reports are given chronologically in the appendix.

There are nearly a half-million miles of cable laid on the sea floor in various parts of the world. In the appendix we have summarized the reported whale damage for about one-sixth of the world's cables. The list is considered complete for all whale 
damage occurring in cables owned by the Commercial, All America, and Western Union companies for the years 1930-1955. The reports of cable damage kept by these companies are not nearly so complete or detailed for the years before 1930 . In the records of the Commercial Cable Company all repairs are listed from the date of

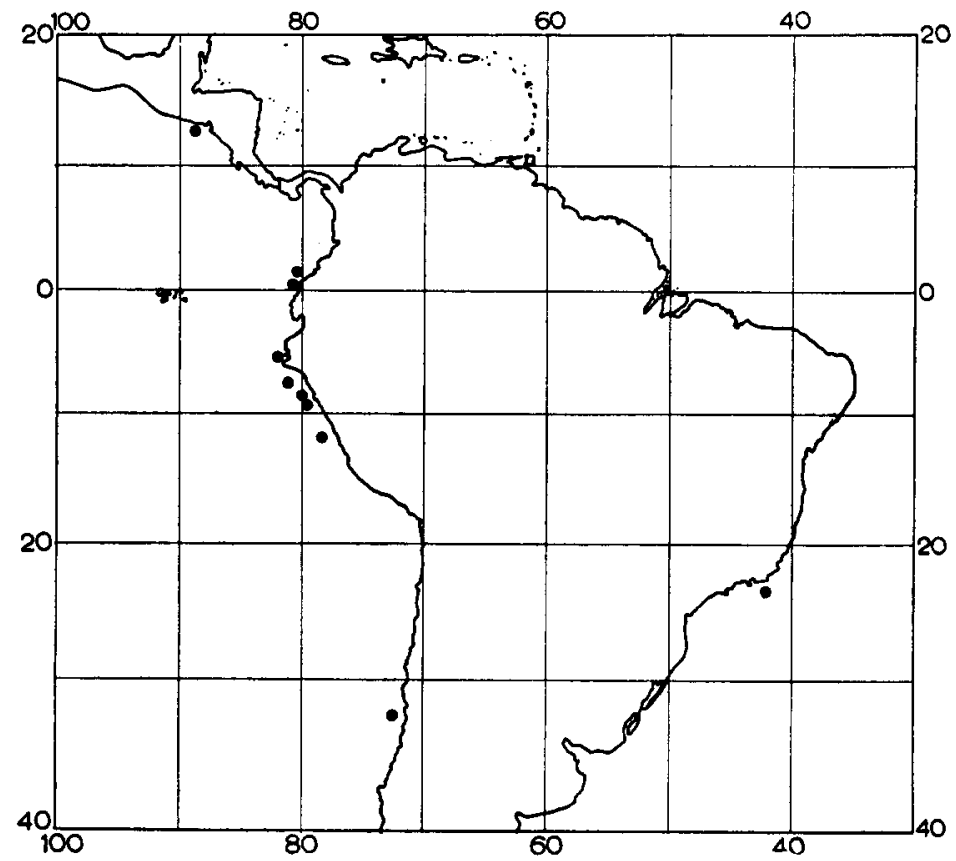

Fig. 1. Locations where whales were found entangled in submarine cables off Central and South America.

Table 1. Cable failure records studied

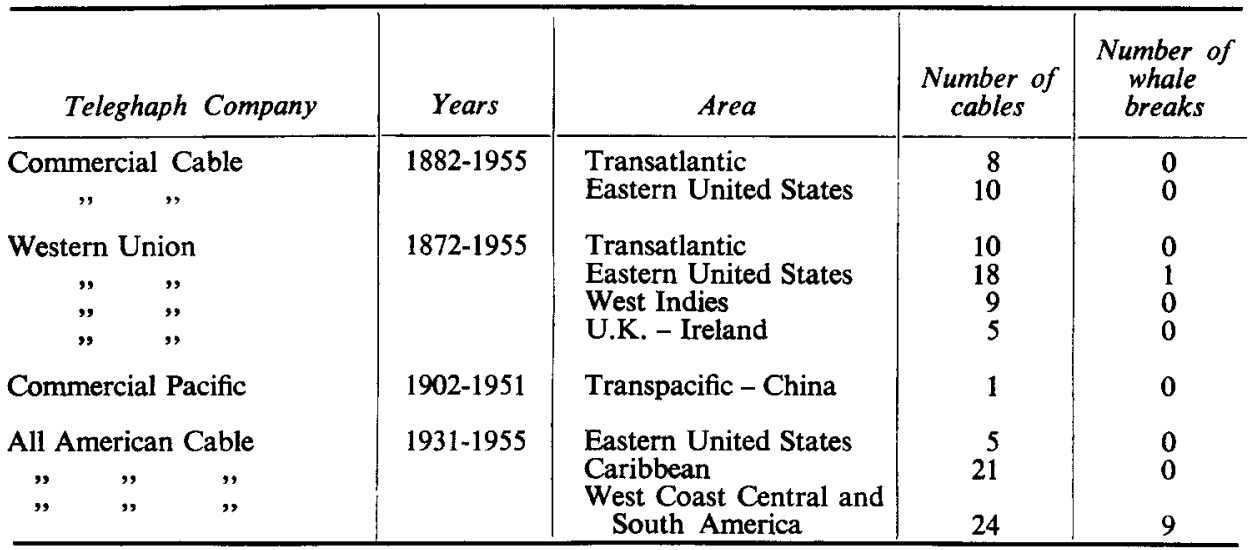

laying to the present. The All America and Western Union records in some instances are not quite so complete. Usually only a few words are devoted to the cause in the existing reports. Most of the detailed reports made before 1930 are no longer available.

A cable company memorandum dated 1905 refers to " whale damage in the Persian 
Gulf (1872), Gulf of Suez (1892), and Prince William Sound (1905)," but gives no other details.

Dr. RAYMOND GILMORE (1955) recalls " one record of a humpback whale in a cable in Alaskan waters in comparatively shallow depths." Many more such reports will undoubtedly turn up as more cables are studied.

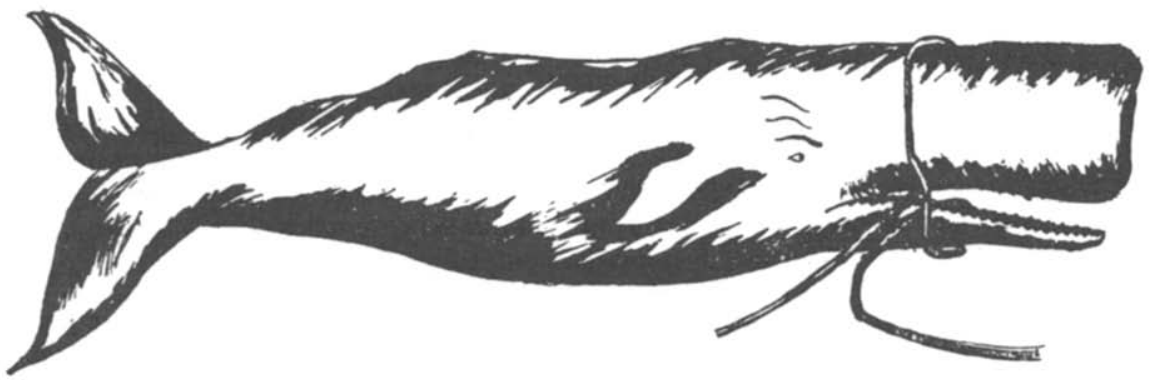

Fig. 2. (a). Drawing made from verbal description given by Captain J. HACK of the whale entangled off Peru in July 1940, in 470 fathoms. (See Appendix, No. 12).

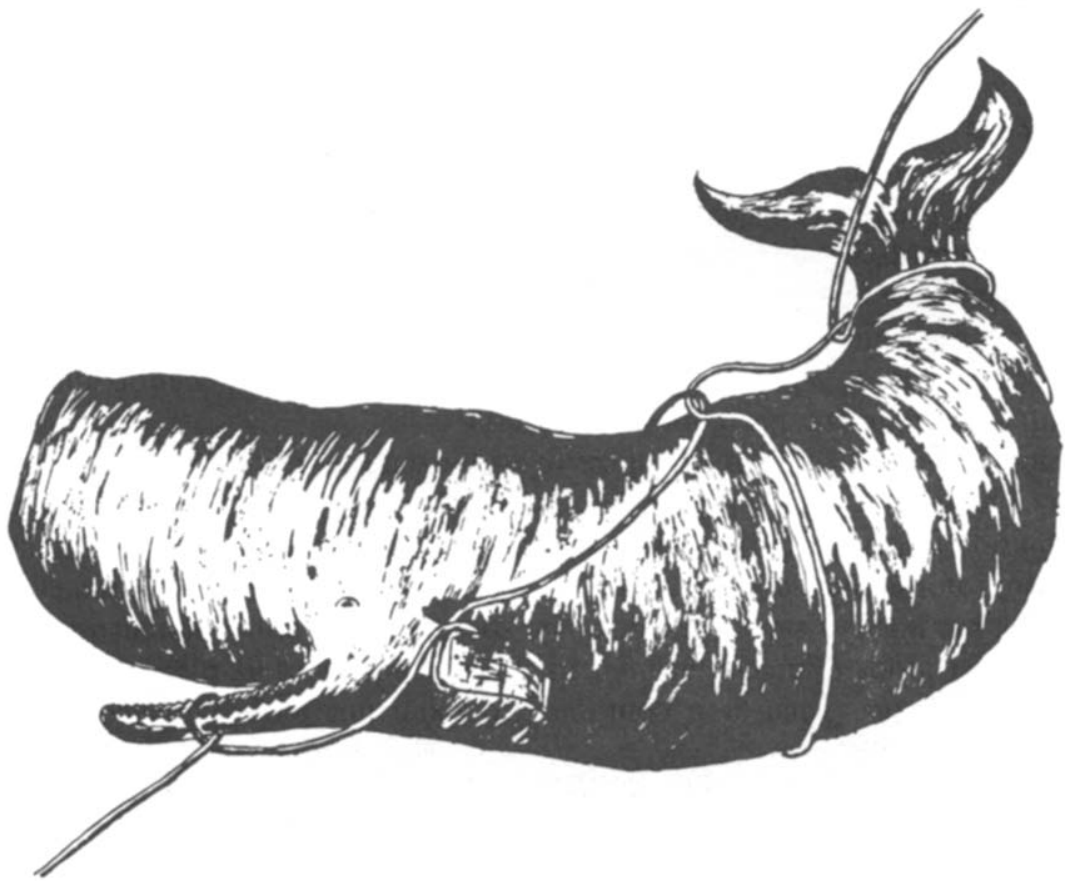

Fig. 2. (b). Drawing made from verbal description given by Captain P. E. HARNE of the whale found entangled March, 1931, off Ecuador in 545 fathoms. (See Appendix, No. 7).

SUMMARY OF KNOWN ENCOUNTERS OF WHALES WITH SUBMARINE CABLES

(1) Location.

Eight cases between $13^{\circ} \mathrm{N}$ and $13^{\circ} \mathrm{S}$ along Pacific coast of America ; one case near Nova Scotia ; one case in the Persian Gulf ; one in Alaskan waters ; one off Cape Frio, Brazil ; one case from somewhere off the west coast and one case from somewhere off the east coast of South America. 
(2) Depth.

(3) Season.

(4) Nature of Entanglement.

(5) Type of Whale.

(7) Type of Damage.

(8) Type of Cable Damaged.
(9) Cable History in the Locality.

Six cases about 500 fathoms ; three cases about 200 fathoms; three cases about 65 fathoms ; two unknown depths.

Five whale carcasses were brought in during February, March and April ; two in July. Whale skeletons were found in August and December, but do not indicate the time of entanglement.

In most cases the cable was wrapped around the whale's jaw and around its flukes (Fig. 2). Some cases were reported when the cable was only wrapped around its fiukes and some when the cable was only wrapped around the whale's lower jaw.

All of those positively identified were sperm whales but those found in shallow water may have been baleen whales (GILMORE, 1955). A humpback whale has been reported caught in a cable in Alaskan waters (GilmORE, 1955).

(6). State of Preservation of Whale Carcass. In seven cases the whales' carcasses were well preserved when brought up. In each of these cases the repair was made 2-7 days after the damage occurred. In one case in 30-70 fathoms the whale's carcass was partly decomposed after only two days and in another case in 70 fathoms decomposition was far advanced after two weeks. On two occasions only the skeleton was recovered, the bod having completely decomposed.

In only one case were the armour wires broken. In all other cases described the insulation was spewed out between the armour wires and in a few cases the conductor was broken.

Damage has occurred in all three of the basic cable types, heavy, intermediate, and deep sea (light). The approximate (good condition) breaking strengths of these types are 20 , 12 , and 10 long tons, respectively.

In most of the cases the cable was damaged by whales at or near a former repair. This probably means that there was extreme slack in the cable at these points.

\section{DISCUSSION}

From a study of the reports (see appendix) it is clear that the whales caused the damage to the cables which necessitated these repairs. They became entangled at the sea floor and not at intermediate depths during the repair. The characteristic mauling type damage and the good correlation between number of days from failure to repair and the state of decomposition of the carcasses support this conclusion.

The possibility that the deep water entanglements involved dead whales transported by water currents, land slides or turbidity currents from shallow water can also be rejected on the basis of the evidence cited above. In addition turbidity currents forceful enough to propel a whale could certainly have broken the armour wires of the cable. Currents would not explain the mode of entanglement or the fact that no whale damage has occurred in depths greater than 620 fathoms.

The question of how the whale became entangled in the cable cannot be answered from the data presented here. However, the most plausible explanation is that as the whale skimmed along the ocean bottom in search of food it encountered the loops (Fig. 3) of an extremely slack cable. The whale may have caught one of these 


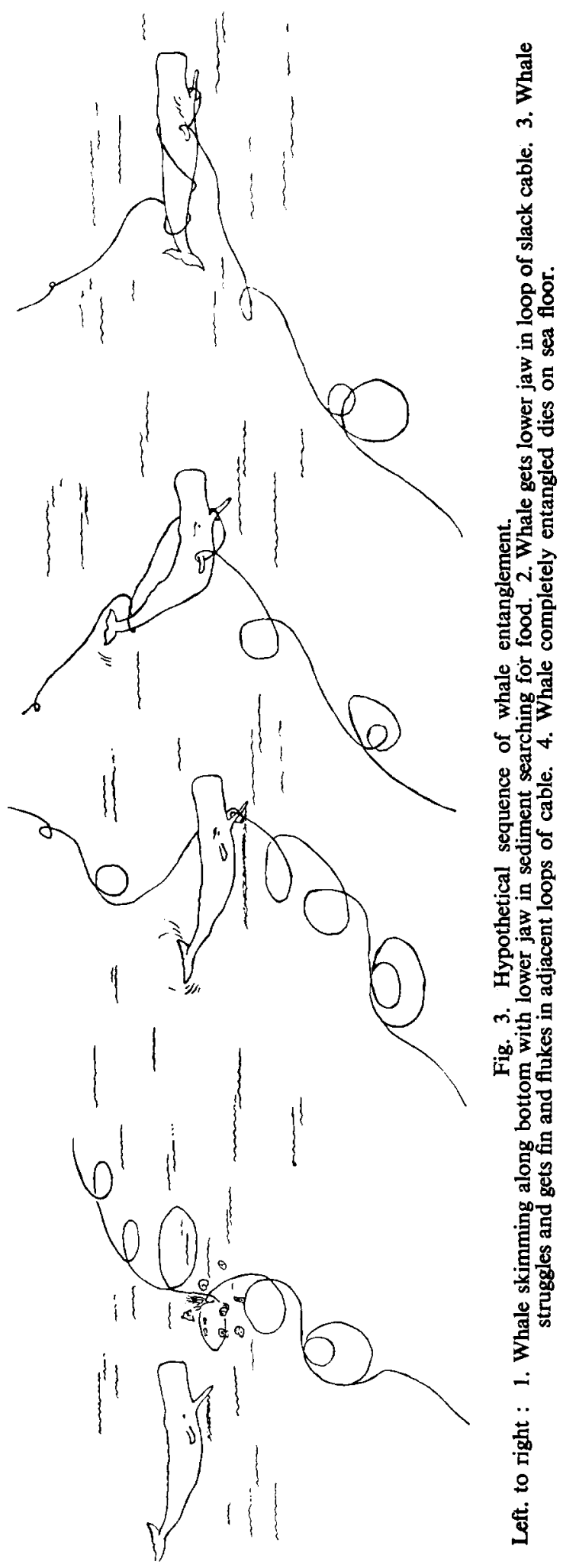


loops in its mouth. Then as it continued to swim this loop tightened around the jaw and other loops tightened around its flipper and flukes as the cable was pulled tight along the whale's side. As the whale struggled the loops tightened so that the whale could not get loose. The whale bit the cable with its teeth and thus squeezed the insulation out through the armor wires, but the whale did not have enough force to break the armour wires of the cable (breaking strength 8-20 long tons). In a few cases the bite of the whale or the effect of its movements in the tightening of a kink was sufficient to break the copper conductor.

The occurrence of whale entanglements off the coasts of Ecuador and Peru in March may be related to the seasonal migration of sperm whales (TowNSEND, 1935), but the number of reported occurrences is not yet sufficient for any firm conclusion.

The high occurrence of breaks at about 500 fathoms may be due to the natural occurrence of food at this depth. It may also be due to extra slack left in cables at this depth. On steep slopes it is difficult to determine the exact depth, and in order not to leave the cable under tension on the bottom, the cable ship masters may have laid out extra slack when engaged in repairs in these areas.

The writer does not pretend to understand the physiology of whales and how they can withstand such large changes in pressure. However, it now seems well-established that sperm whales often swim near the bottom in depths as great as 620 fathoms. It seems plausible that the whales become entangled in the submarine cables while swimming along in search of food, with their lower jaw skimming through the upper layer of sediment. It may also be that the whales attacked the cable mistaking it for prey.

\section{APPENDIX*}

\section{Reports of Whales Entangled in Cables}

\section{Kurrachee (Pakistan) - Owadur Cable}

This cable was reported interrupted by a whale in 1877 or 1878 in a note published in the Scientific American Supplement for March 9th, 1878.

" Mr. Isaac Walton, superintendent of telegraphs for Mekran and the Persian Gulf, reports as follows to the government at Bombay: "The cable from Kurrachee to Owadur, about 300 miles long, was suddenly interrupted on the evening of the 4 th inst. The telegraph steamer, Amberwitch, Captain Bishop, with the staff of engineers and electricians, under the orders of Mr. Hy. C. Mace, started next day to repair the fault, which was estimated to be 116 miles from Kurrachee, according to the tests taken from both ends.

“" The Amberwitch arrived at this place at two o'clock in the afternoon of the 6th. The sea was rough, and there was a thick fog at the time, but the cable was nevertheless hooked at a quarter of a mile from the point of rupture.

". The soundings taken about the place of this break were very irregular, and showed a jump from 70 to 30 fathoms. In hauling in the cable an unusual strain was experienced, as if the cable had fouled, a rock, but on persevering for some time the body of an enormous whale, entangled in the cable, was brought to the surface ; it was found to be firmly held by two and a half turns of the cable, taken immediately above the tail. Sharks and other fish had partly devoured the carcass, which was rapidly decomposing, the jaws coming adrift on arriving at the surface. The tail, which was twelve feet wide, was perfectly preserved, and was covered with numerous shells at its extremities. Apparently the whale had rubbed itself against the cable for the purpose of ridding itself of parasites, and had with a stroke of the tail broken the cable, and, at the same time, so coiled itself up in it as to be strangled thereby." "

*A Fault : A failure in insulation but with conductor continuity between the two terminal stations. An Interruption : A complete rupture of the conductor severing all communication.

Nauts : Nautical Miles. 


\section{Cable belonging to the West Coast of America Telegraph Company}

A cable belonging to this company was reported broken by a whale in a letter written to the (London) Times.

August 14th, 1884, "A WHALE'S ADVENTURE"---"Sir : As a matter of curiosity and unique experience in connection with the working of submarine telegraph cables, I beg leave to hand you some extracts from the letters from our manager on the West Coast of South America and also from the Captain of our cable repair steamer.

"Judging from the extracts, it would seem that the whale voluntarily attacked the cable, and having had a free fight with it, paid for his temerity with his life, for he was held prisoner for seven days and then mangled unto death.

" The Captain of our repairing steamer writes : - " Having picked up 21 knots of cable, while continuing picking up, an immense whale came up to the bows entangled in the cable. It seemed to be about 70 feet in length. In its struggles to get free, the cable cut right into its side, the whole of its entrails coming out, and great streams of blood. In its last dying struggle it parted the cable on the tow sheaves and floated to windward of the steamer. The cable was twisted up in the form of a wire rope for about two fathoms, and in six different parts it had the appearance of having been bitten through sufficiently to stop all communication. There is no doubt the whale has been the cause of the interruption.'

"Our Manager also writes: "The cause of the breakage of the cable, as has been pointed out to you in Captain Morton's report, was a huge whale which became entangled in the turns of the cable, and was held prisoner for seven days ; the interruption was unfortunate, but it is, at least, satisfactory to know that the cable did not give way naturally, and that where picked up, the sheathing, yard and core were found to be in an almost perfect state of preservation, in fact, looked as good as on the day the cable was first laid.

August 12 (1884)

(Signed) Robinson Kendal, Chairman

The West Coast of America Telegraph Co.

(Limited)"

\section{Brazilian Cable}

The Nautical Magazine (1900) reports : " The Brazilian cable indicated a fault, in 1892, at about 70 miles from the land, requiring an expedition for repairs. It is said that the carcass of a huge whale was found entangled in the cable. When brought to the surface the cable was discovered wound round the cetacean, and it had been twisted by him into a complicated system of knots while in his death struggle."

Unfortunately no data as to depth or position were given.

\section{Rio de Janeiro Cable (Western Telegraph Company)}

The Electrical Review (Vol. 41, No. 1034, p. 382) of September 17th, 1897, carried the following note :

" STRANGE CAUSE OF A CABLE INTERRUPTION" : “A correspondent writing from Rio de Janeiro under date August 25th, 1897, informs us that on August 22nd, whilst the telegraph ship NORSEMAN was engaged picking up cable off Cape Frio, she brought up a whale which had become entangled with the cable. The cable had not parted, but the conductor was interrupted. The whale had probably been there some two or three weeks judging by its condition, its head breaking off during the picking up. It had been much worried by sharks. It measured 14 feet across its tail. The depth of water there is 66 fathoms, soft mud and clay bottom. Latitude $23^{\circ}-17 \frac{1}{2} \mathrm{~S}$, Longitude $41^{\circ}-40 \frac{t^{\prime}}{} \mathrm{W}$."

\section{Hammel (New York) - St. Pierre Cable}

On July 25th, 1919, this cable was interrupted along the west side of the Cabot Strait channel. The cable was repaired the same day. When the cable was brought to the surface it was found that " the body of a whale was tangled in the cable." The depth along the repair varied from 113 to 152 fathoms and the position was $46^{\circ} 05^{\prime} \mathrm{N}, 58^{\circ} 40^{\prime} \mathrm{W}$. 


\section{Cable belonging to All America Cable Company on Pacific Coast of South America}

In a letter to Mr. Wilbur G. Sherman concerning the March 1931 case (\#7), A. Hyatt Verrill reported :

"The sperm thus found entangled with the cable by Captain Harne was his second experience; the other whale was found several years ago and was much larger, although so badly decomposed the repair crewe were forced to cut the cable and let the body go without getting close enough to examine it. That one also had its lower jaw entangled in the cable. Captain Harne is not certain about the depth in that instance but as he recalls, it was about 200 fathoms.

Reprinted from New Bedford Standard in the Nantucket Inquirer and Mirror April 9, 1932

Dr. Raymond Gilmore (1955) recalls that :

“Dr. Austin Clark of the Smithsonian said that he received from Mr. Archibald Pender of the All America Cable Company a report of a sperm whale in the cable at about 500 fathoms off Valparaiso (Chile) sometime in the 1920's."

\section{Buenaventura (Colombia) Santa Elena (Ecuador) 1882 Cable}

This section became faulty on March 3, 1931, and was restored on March 10, 1931. A message from the All America stated :

" Fault found at ten miles from yesterday's cut in position, caused by whale entangled in cable."

The position of the fault was given as latitude $1^{\circ} 10^{\prime} \mathrm{N}$, longitude $80^{\circ}-08^{\prime} 30^{\prime \prime} \mathrm{W}$, depth 545 fathoms, about 15 nautical miles northwest of Esmeraldas.

The New York Times of April 26, 1931, published the following item :

" WHALE CAUGHT IN CABLE DROWNS AT SEA BOTTOM

BalboA, C. Z., April 19 (1931). The record catch of the present fishing season, a ninetyton whale, was made by Captain P. R. Harne of the cable repair ship All America while investigating the cause of recent interruptions in the service of the All America Cable Company's line between here and Esmeraldas, Colombia. The monster was hoisted from a depth of 3,000 feet off the coast of Colombia by the cranes and winches with which the cable ship is equipped.

The whale was dead, having drowned, according to Captain Harne, when it became entangled in the cable. Captain Harne's theory, based upon similar experiences, is that the whale was feeding by scooping along the ocean bed. Digging too deeply in search of food, it picked up the cable, which snarled over its lower jaw. Then in turning over to free itself the whale wrapped the cable around its throat. Its frantic efforts to get free only tended to entangle it more completely in the cable, thirty fathoms of which was coiled around its body when brought to the surface.

There were no marks to indicate that carnivorous fish had attempted to feed on the huge carcass of the creature. This is explained, according to Captain Harne, by the fact that the whale, protected by a heavy coat of blubber is able to withstand the high pressure of greater depths than other fish, which could not descend three-quarters of a mile to the bottom where the creature's body was moored to the cable.

In order to free the whale it was necessary to cut the cable and splice in a new section. Once freed, the huge carcass drifted away."

In a letter to Wilbur G. Sherman concerning this incident, A. Hyatt Verrill reports as follows :

"In a recent conversation with Captain Harne, he showed me your letters of last summer asking for details in regard to the whale he found entangled in a cable off Ecuador, South America. The whale was a sperm, about 45 feet in length, which had unusually large teeth and was a bull. There was a turn of the cable around the lower jaw, another around one flipper and still another around the flukes (tail). The cable was on the bottom at a depth of 540 fathoms off Esmeraldas, Ecuador, and it was necessary to clear the damaged whale's body by cutting the cable on each side and then splicing the cut ends to restore service operated by the All America Cable Company from Panama." 
Reprinted from the New Bedford Standard in the Nantucket Inquirer and Mirror, April 9, 1932

LAURIE (1933, p. 369), probably referring to this case, states :

" A case was related to me in 1931 of a dead sperm whale which was found off the Peruvian coast entangled in a submarine cable which had broken at a depth of 500 fathoms. The mate of the cable ship, "All America," informed me that when the cable was hauled to the surface it was caught in the angle of the whale's jaws and a loop was twisted around the tail. From these observations it is probable that the whale became entangled in the cable while actively engaged, possibly in the pursuit of cephalopod."

\section{Balboa (Canal Zone Santa Elena (Ecuador) 1913 Cable}

Repaired in April 1932. The cable was brought to the surface off the coast of Colombia. Entangled in it was a dead 45 foot male sperm whale. The submarine cable was twisted around the lower jaw and was wrapped around one flipper, the body and caudal flukes. The cable was raised from a depth of 540 fathoms. This report was taken from Carson (1951). However, it has not been found in cable company records.

\section{Paita (Peru) Chorrillos (Peru) 1882 Cable}

On March 13, 1932, communication between Paita and Chorrillos was interrupted with tests placing the break about 77 nautical miles from the former station. Two days later the vessel started repair operations and hooked into the section. Log extracts state that after cutting in and picking up some 2 nauts, " a dead whale broke surface entangled with the cable, cable having a turn round lower jaw." (Position : Latitude $8^{\circ} 55^{\prime} 21^{\prime \prime} \mathrm{S}$, Longtitude $81^{\circ} 18^{\prime} 09^{\prime \prime} \mathrm{W}$, depth 255 fathoms).

It is interesting to note on this occasion, as well as in (7), that while the armour of the cable was distorted and displaced it still held at the point where the whale, in its violent death throes, had spewed out the insulated core from under the lay of the steel wires. In (7), however, the copper conductor was not severed while in (9) the entire core, copper and gutta percha had parted.

\section{Chorrillos (Peru) Iquique (Chile) 1927 Cable}

This section was reported interrupted on February 21, 1933, with tests placing the trouble about $44 \cdot 5$ nautical miles from Chorrillos. Here again the repair pattern was similar to (7) and (9). The ship hooked into the line as indicated by tests and after picking up north for $\cdot 77$ nauts a dead whale broke surface with bight of cable under jaw and around tail. (Position : Latitude $12^{\circ} 46^{\prime} 48^{\prime \prime} \mathrm{S}$, longitude $77^{\circ} 42^{\prime} 00^{\prime \prime} \mathrm{W}$, depth 442 fathoms). Once more the sheathing wires were holding fast with the core spewed out and severed.

\section{Salina Cruz (Mexico) La Libertad (San Salvador) 1882 Cable}

March 21, 1935, the above section was reported silent. As in (9) and (10) tests indicated a complete interruption. Unfortunately when this circuit was lost cable ship All America was otherwise occupied and could not proceed on its restoration until some two weeks later. On this occasion the cable had been completely broken by the antics of the whale (latitude $12^{\circ} 58^{\prime} 36^{\prime \prime} \mathrm{N}$, longitude $89^{\circ} 28^{\prime} 51^{\prime \prime} \mathrm{W}$, depth 68 fathoms) and after two weeks immersion decomposition of the carcass had commenced.

The following, which appeared in the Panama America 5/17/35, tells the story more graphically :

"Despite the fact that corrosion is the usual reason for the destruction of the cables of the All America Cable Company, whales, too, play an important part in the wearing process.

"According to the officers of the All America, the cable company's ship which is now in the Balboa drydock, a recent job on a cable which runs from Salina Cruz to San Salvador proved a whale of an undertaking. Having received word in the usual manner that a section of the cable in that area had parted, the All America sped to the place where they believed the repair job was to be made.

"In the early evening of April 5, the break in the cable was located and the broken section was being lifted to the surface.

"As the end was dragged up the cable became heavier instead of lighter. Suddenly with a loud splash the disintegrated body of a giant whale with the end of the servered 
cable wrapped securely about it, broke the surface of the sea. It was not a hard job getting the cable unwound for the whale had been dead so long that it immediately broke off in pieces and floated away.

"The tropic sea was fragrant no longer and as the officers and crew of the cableship leaned over the side to gaze in silent wonder at the huge body of the unusual mammal they held their noses with diligence."

\section{Paita (Peru) Chorrillos (Peru) 1882 Cable}

This section again suffered whale trouble on July 26,1940 . As before tests gave indications that the cable had been completely interrupted. On July 30th repair operations were started. Once more the usual whale sequence followed. The ship hooked in, picked up towards the test location and, on reaching it a dead whale broke surface with one turn of cable completely around head and two around jaw. (Position : approximately, latitude $6^{\circ} 23^{\prime} \mathrm{S}$, longitude $81^{\circ} 08^{\prime} \mathrm{W}$, depth 470 fathoms). Up until the whale surfaced the armouring wires of the cable held but on maneuvering the vessel to cut away the carcass, too much stress was applied and the cable parted.

With the whale floating, and still firmly attached to the northern side of the cable leading to Paita, it was used as a mark buoy to establish a reference point from which to grapple and raise the line again. From this it is evident that, although foul of it, the whale did not sever the cable armouring.

Captain Hack's description of the mode of entanglement was sufficiently complete to allow the preparation of a drawing (Fig. 2a). A crewman of the All America took two pictures of a whale entangled in the cable (Figs. 4 and 5).

\section{Santa Elena (Ecuador) Chorrillos (Peru) 1893 Cable}

On December 30,1944, while engaged in making a repair to this section the skelton of a whale's jaw was found foul, of the cable in latitude $9^{\circ} 07^{\prime} 18^{\prime \prime} \mathrm{S}$, longitude $80^{\circ} 00^{\prime} 30^{\prime \prime} \mathrm{W}$, depth 560 fathoms. This, however, did not cause the interruption.

\section{Santa Elena (Ecuador) Chorrillos (Peru) 1893 Cable}

This cable was reported faulty on August 10, 1955. On October 14, 1955, the Cable Ship All America repaired the fault. The captain made the following report :

"Jawbone of whale came inboard in bight of cable on Chorrillos end. Cable ridden and this was evidently cause of fault. Cleared whale bone and bight before splicing cable."

Position : latitude $09^{\circ} 00^{\prime} 30^{\prime \prime} \mathrm{S}$, longitude $80^{\circ} 06^{\prime} 31^{\prime \prime} \mathrm{W}$, depth 620 fathoms.

A photograph of the whale jaw and the damaged cable obtained from the captain by Mr J. H. F. Petch is shown in Fig. 6. This entanglement in 620 fathoms is the deepest ever reported.

\section{REPORTS OF CABLE FAILURES POSSIBLY ATTRIBUTABLE TO WHALES}

\section{A. Sidney (Australia) Nelson (New Zealand) Cable}

The Electrical Review 49, 1251, 808 of November 15, 1901, carried the following note : " THE CAUSE OF A CABLE INTERRUPTION. A fault removed a few months ago from the Eastern Extension Telegraph Company's Sidney - Nelson section at as great a depth as $\mathbf{3 3 0}$ fathoms was found to contain a tooth firmly fixed in the core or interior portion of the cable containing the conductor, although it was protected by the usual sheathing of thick iron wires and outer coverings. An expert examination of the tooth proved it to belong undoubtedly to a shark, the exact variety of which could not be identified. Five species are known to exist in a depth of 300 fathoms, and one as deep as 500 fathoms."

\section{B. Malaga (Spain) - Lisbon (Portugal) Cable. (Cable and Wireless)}

This cable was repaired August 29, 1951 by the cable ship Mirror, 33.2 Nautical Miles from Lisbon in 700-1665 fathoms. The positions and depth given for the two splices are $38^{\circ} 14^{\prime} \mathrm{N}, 09^{\circ} 33^{\prime} \mathrm{W}$, 700 fathoms, and $38^{\circ} 09^{\prime} \mathrm{N}, 09^{\circ} 35^{\prime} \mathrm{W}, 1665$ fathoms.

Captain J. C. West's report states that: "The original defect was core breaks in original 1929 cable, at an unbelievably knotted tangle of bights caused by a large fish fouling cable. A one pound lump of soft, tough, amorphous fish tissue, highly oderiferous was tightly wrapped around the cable and subsequently cut clear with difficulty." 


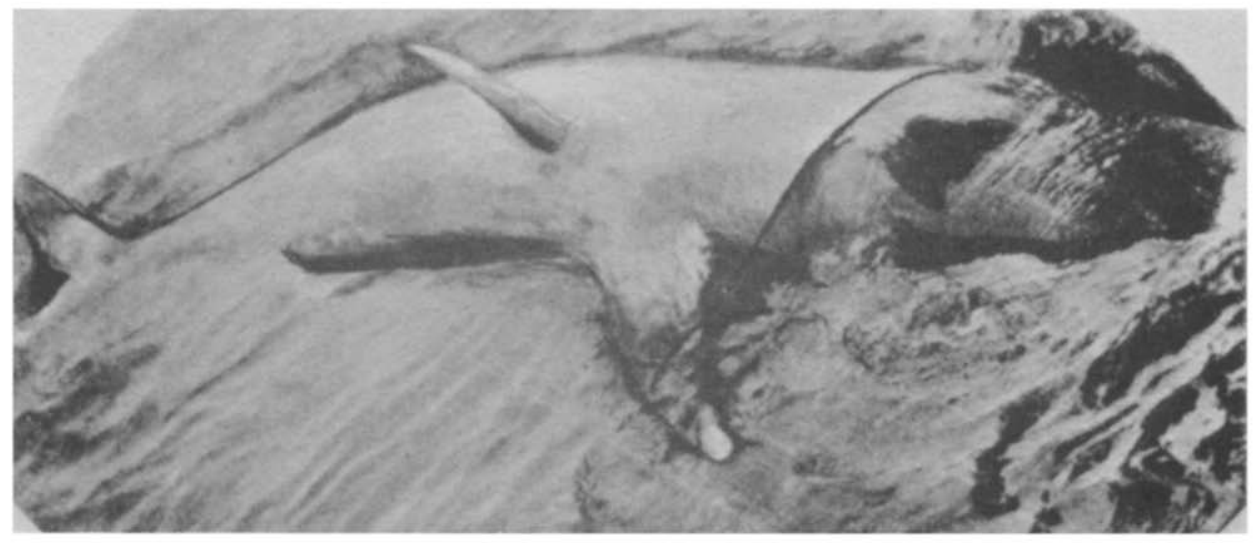

Fig. 4. Photograph of a male sperm whale found entangled off Peru. Whale is floating in the water with the cable wrapped around its jaw. One end of the cable is on board the cable ship ; the other end extends to the sea floor. The photograph was made with slightly fogged film and has been slightly retouched. 30 July, 1940. (See Appendix, No. 12).

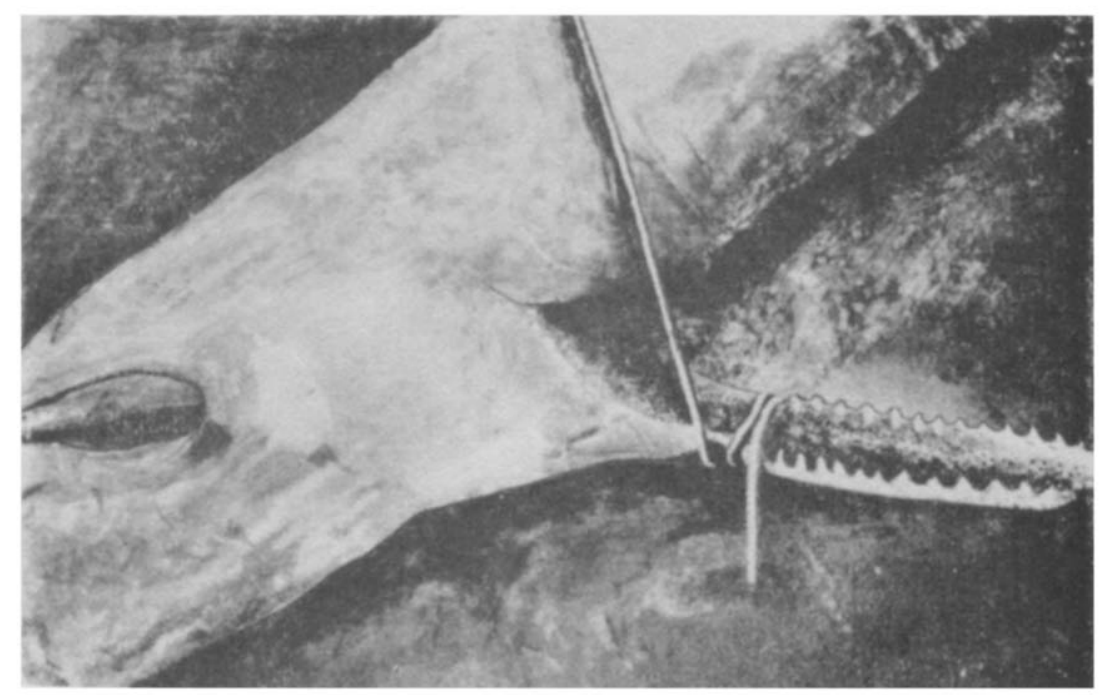

Fig. 5. Close up of same whale shown in Fig. 4 showing cable wrapped around whale's jaw and head. (See Appendix, No. 12). Depth 470 fathoms ; 30 July, 1940, off Peru. Photograph retouched slightly. 


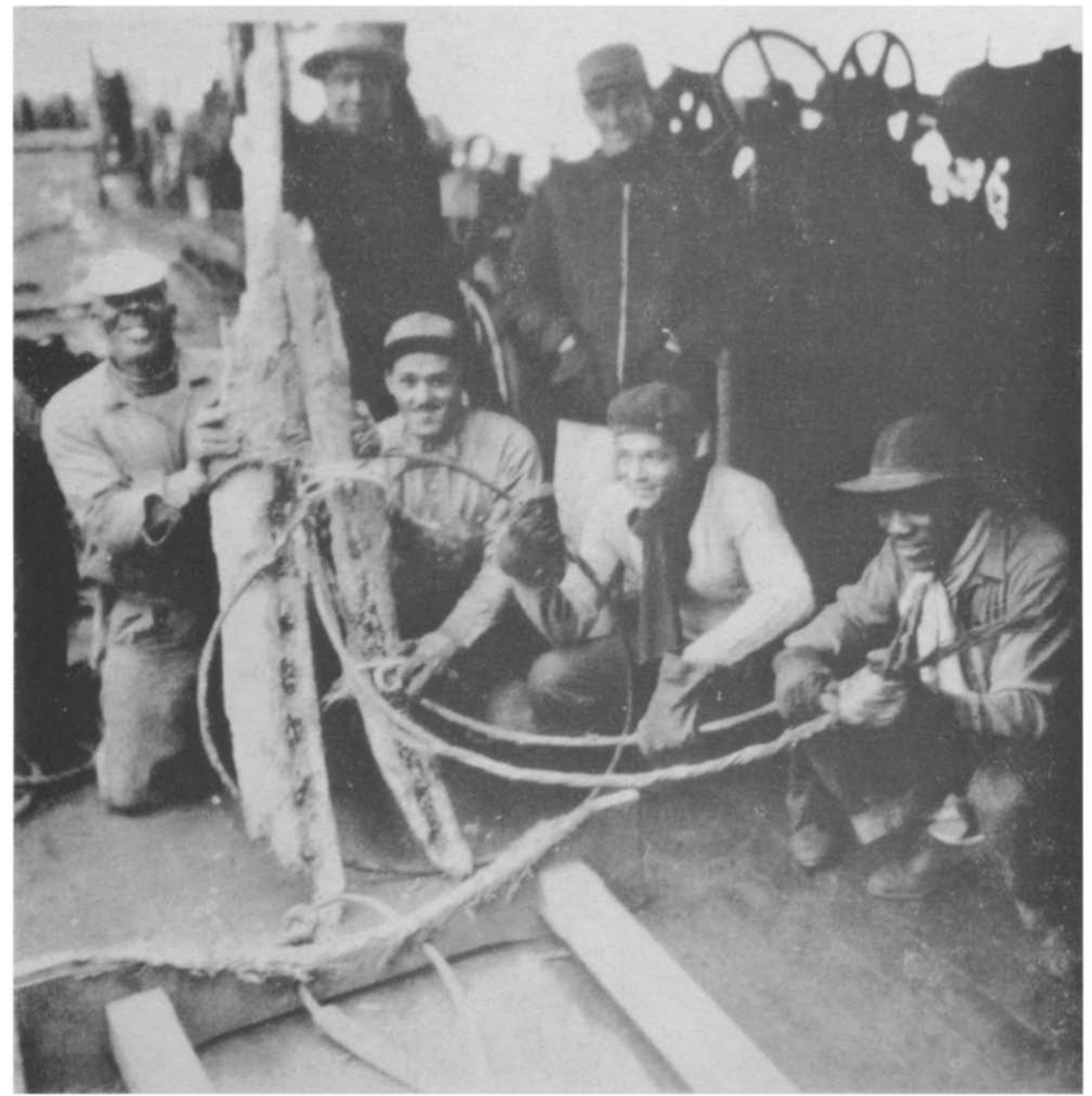

Fig. 6. Photograph of whale's jaw and mauled cable brought up from 620 fathoms off Peru on October 14th, 1955. (See Appendix, No. 14). 
The captain believed the depth (1200 fathoms) too great for whales and suggested the break was caused by an octopus. He concluded that the animal was large and powerful judging from the extent of the damage inflicted to the fairly new cable.

Acknowledgements-Professor MAURICE EwING called the writer's attention to the entanglement of whales in deep sea cables and encouraged him to undertake the present study.

Much of the information in the present report was supplied by H. J. ROSENBERGER, Assistant Chief Engineer, All America Cable and Radio Company, New York. C. S. Lawton, General Plant Engineer, International Communications, Western Union Telegraph Company, provided information on the repairs of his company's cables. J. HACK and J. P. F. PetCH of the All America Cable Company gave a firsthand account of the 1940 repair. C. C. TAYLOR of the Commercial Cable Company provided additional details. Remington KellogG, Director, and DAvid H. JohNSON, Acting Curator, Division of Mammals, U.S. National Museum, provided helpful clues to published newspaper reports. R. J. Menzies and R. BIERI of the Lamont Geological Observatory made helpful suggestions. RAYMOND M. GILMORE of the U.S. Fish and Wildlife Service read the manuscript and made several valuable suggestions. W. E. Schevill of the Woods Hole Oceanographic Institution and G. E. R. DEACON of the (British) National Institute of Oceanography offered encouragement. How ARD Foster assisted in searching cable failure reports and retouched the photographs. MARIE THARP drew the illustrations. The preparation of this paper was supported in part by the Bureau of Ships, U.S. Navy, under Contract NObsr 64547.

\section{Lamont Geological Observatory}

Columbia University

Palisades, New York

Contribution No. 234 from Lamont Geological Observatory.

\section{REFERENCES}

ANon (1878) Scientific American Supplement 5, 114, 1815.

ANon (1897) Strange Cause of a Cable Interruption. Electrical Review 41, 1034, 382.

ANON (1900) Notes on Whales and Whaling. Nautical Magazine 336.

ANON (1901) Cause of a Cable Interruption. Elect. Rev. 49, 1251, 808.

Anon (1931) Whale Caught in Cable Drowns at Sea Bottom. New York Times, April 19. CARSON R. (1951) The Sea Around Us pp. 169. Oxford University Press.

Gilmore R. (1955) Personal Communication.

Kendal R. (1884) A Whale's Adventure. The Times (London), August 12.

LAurie A. H. (1933) Some Aspects of Respiration in Blue and Fin Whales. Discovery Reports 7, 369.

Townsend C. H. (1935) The Distribution of Certain Whales as Shown by Logbook Records of American Whaleships. Zoologicd, N.Y. 19 (1), 3-50.

Verrill A. H. (1932), Letter to W. G. Sherman. Nantucket Inquirer and Mirror, April 9. 